ROCZNIKI NAUK PRAWNYCH

Tom XXXI, numer 3 - 2021, s. 39-55

DOI: http://doi.org/10.18290/rnp21313.3

DARIUSZ MUCHA

Uniwersytet Opolski

dariusz.mucha@uni.opole.pl

ORCID: https://orcid.org/0000-0003-2162-5635

\title{
NIEWYKONANIE KARY OGRANICZENIA WOLNOŚCI A ZASTĘPCZA KARA POZBAWIENIA WOLNOŚCI
}

\author{
FAILURE TO SERVE THE SENTENCE OF RESTRICTION OF LIBERTY \\ AND SUBSTITUTIVE IMPRISONMENT
}

\begin{abstract}
The article refers to the final stage of execution of the sentence of restriction of liberty in the event the convicted offender does not serve the sentence and is subject to a substitute sentence of imprisonment. It analyses and evaluates the ending of the proceedings in the field of restriction of liberty as a result of the judgment and execution of a substitute sentence due to failure of the convicted offender to serve the sentence of restriction of liberty. In particular, as the most far-reaching alternative, it discusses a legally admissible solution for modifying the sentence imposed originally on a specific offender and changing its duration in the final judgement. Finally, it analyses and evaluates the current state of the law, highlighting its shortcomings and doubts in practical terms, relating them to the powers exercised by the court and the parties to the enforcement proceedings.
\end{abstract}

Keywords: evasion; substitutive imprisonment; abstention

\section{WPROWADZENIE}

Poniższe rozważania odnoszą się do ostatniego etapu wykonawczego kary ograniczenia wolności w przypadku jej niewykonania przez skazanego na nią sprawcę przestępstwa w kontekście orzeczenia wobec niego zastępczej kary pozbawienia wolności. Już na wstępie należy podkreślić, iż moim zdaniem niewykonanie kary ograniczenia wolności może mieć również początek już na przedpolu jej orzeczenia ${ }^{1}$. $Z$ uwagi jednak na zakres tematyki zakre-

${ }^{1}$ Zob. D. MuchA, Zgoda skazanego na orzeczenie kary ograniczenia wolności - fikcja czy prawda?, „Opolskie Studia Administracyjno-Prawne” 2016, nr 1, s. 77-88. 
ślony tytułem niniejszego artykułu, ową problematykę związaną z samym orzeczeniem tej kary celowo pomijam. Główne zagadnienie, które zamierzam omówić, to podstawowe problemy związane $\mathrm{z}$ charakterem prawnym rozwiązania przewidzianego $\mathrm{w}$ art. 65 Kodeksu karnego wykonawczego, sprowadzającego się do zakończenia postępowania w zakresie kary ograniczenia wolności na skutek orzeczenia i wykonania kary zastępczej z uwagi na niepozytywne zakończenie wykonania kary ograniczenia wolności przez skazanych. Od właściwego zinterpretowania i zastosowania tej normy prawnej zależy prawidłowe stosowanie w praktyce na etapie postępowania wykonawczego instytucji kary zastępczej pozbawienia wolności za niewykonanie kary ograniczenia wolności. Jest to najdalej idące alternatywne prawnie dopuszczalne rozwiązanie modyfikujące rodzaj orzeczonej pierwotnie kary i jej wymiar wymierzonej w orzeczeniu końcowym wobec określonego sprawcy czynu zabronionego ${ }^{2}$.

\section{ZAGADNIENIA WSTĘPNE}

Obowiązujący Kodeks karny wykonawczy z 6 czerwca 1997 r. ${ }^{3}$ od dnia 1 stycznia 2012 r. za sprawą zmian, jakie w tym właśnie dniu weszły w życie w brzmieniu normy prawnej z art. 65 k.k.w., przewiduje wyłącznie orzeczenie zastępczej kary pozbawienia wolności ${ }^{4}$. Ustawodawca - jak się wydaje uznał, że zamiana kary surowszej na łagodniejszą jest rozwiązaniem niecelowym i nieracjonalnym, przesłance takiemu założeniu przeczy norma prawna z art. 75a Kodeksu karnego, która takie uznanie przełamuje. Sąd orzeka zastępczą karę pozbawienia wolności, gdy stwierdzi, że skazany uchyla się od wykonania kary ograniczenia wolności.

Uchylanie się od kary jest pojęciem ustawowo niedookreślonym. Jako znamię używane w ustawach karnych - jak zauważa Monika Cendrowska - wiąże się ono z zachowaniem „zawinionym” na skutek umyślnego, lekkomyślnego czy chociażby rażąco niedbałego postępowania, nierzadko cechującego się wręcz złośliwością ${ }^{5}$. Jeszcze do niedawna powszechną praktyką sądów było

\footnotetext{
${ }^{2}$ Warto w tym miejscu przypomnieć, że kara ograniczenia wolności jako sankcja karna obecnie nie podlega warunkowemu zawieszeniu wykonania.

${ }^{3}$ Tekst jedn.: Dz.U. z 2021 r., poz. 53 [dalej k.k.w.].

${ }^{4}$ Art. 65 k.k.w. zmieniony przez art. 1 pkt 30 ustawy z dnia 16 września 2011 r. o zmianie ustawy - Kodeks karny wykonawczy oraz niektórych ustaw, tekst jedn.: Dz.U. z 2021 r., poz. 53.

${ }^{5}$ M. CENDROwsKA, Sylwetka kuratorów sadowych oraz ich opinie na temat wykonywania kary ograniczenia wolności, [w:] Z problematyki badań empirycznych $w$ prawie karnym wykonawczym, red. A. Kwieciński, Wrocław: Wydawnictwo Uniwersytetu Wrocławskiego 2015, s. 80.
} 
niepremiowanie faktu przy wyroku łącznym z uwagi na obowiązującą regulację w tym zakresie i jej wykładnię w sytuacji, gdy skazany dobrowolnie przystąpił do wykonania kary ograniczenia wolności i ją wykonywał bez żadnych zastrzeżeń sądu ją nadzorującego. Za takim stwierdzeniem przemawiała bowiem gramatyczna wykładnia przepisu art. $87 \S 1$ k.k. ${ }^{6}$, odnosząca się do orzeczenia kary łącznej w przypadku skazania za zbiegające się przestępstwa na kary pozbawienia wolności i ograniczenia wolności, kiedy to sąd obligatoryjnie z mocy prawa wymierzał wobec takiego skazanego karę łączną pozbawienia wolności. Sąd z uwagi na brzmienie tego przepisu (zawarte w nim ustawowe przesłanki) nie miał możliwości odstąpienia od orzeczenia kary ograniczenia wolności ${ }^{7}$. W tej kwestii wypowiedział się ostatecznie Trybunał Konstytucyjny (TK), który w wyroku z dnia 11 czerwca 2019 r. stwierdził, że przepis art. $87 \S 1$ k.k. w zakresie, w jakim nakłada na sąd obowiązek połączenia kar pozbawienia wolności i ograniczenia wolności oraz wymierzenia kary łącznej pozbawienia wolności po dokonaniu zmiany kary ograniczenia wolności na karę pozbawienia wolności, jest niezgodny z art. 45 ust. 1 i art. 175 ust. 1 Konstytucji Rzeczypospolitej Polskiej ${ }^{8}$. W uzasadnieniu prawnym do tego orzeczenia czytamy m.in., że:

Art. $87 \S 1$ k.k., stosowany w postępowaniu o wydanie wyroku łącznego, następczo niweczy gwarancję swobody orzekania, z której korzystał sąd wydający wyrok za jedno ze zbiegających się przestępstw, i pozbawia takiej swobody sąd, który ma obowiązek wydać wyrok łączny. (...) W konstytucyjnym standardzie sprawowania wymiaru sprawiedliwości przez sądy nie mieści się sytuacja, w której ustawodawca wyłącza możliwość skutecznego wykonania kary ograniczenia wolności, wcześniej prawomocnie orzeczonej przez niezawisły sąd i nakazuje sądowi, który ma obowiązek wydać wyrok łączny, obligatoryjne zamienić tę karę na karę pozbawienia wolności po dokonaniu przeliczenia zgodnie z zasadami wskazanymi w ustawie ${ }^{9}$.

Ten wyrok TK zdaniem Sądu Najwyższego nie wyłączył możliwości łączenia kary pozbawienia wolności z karami ograniczenia wolności w trybie przepisu art. $87 \S 1$ k.k., „lecz zastąpił obowiązek orzekania w takiej sytuacji kary łącznej pozbawienia wolności kompetencją jej wymierzenia, pozwalają-

${ }^{6}$ Ustawa z dnia 6 czerwca 1997 r. - Kodeks karny, tekst jedn.: Dz.U. z 2020 r., poz. 1444 [dalej: k.k.].

${ }^{7}$ D. Mucha, Kara ograniczenia wolności - instrukcja obstugi, [w:] Kary jako podstawowe sankcje w prawie karnym, red. S. Hoc, D. Mucha, Opole: Scriptorium 2018, s. 168.

${ }^{8}$ Konstytucja Rzeczypospolitej Polskiej z 2 kwietnia 1997 r., Dz.U. Nr 78, poz. 483 ze zm. Wyrok TK z dnia 19 czerwca 2019 r., P 2-/17, OTK-A 2019/29, Dz.U. z 2019 r., poz. 1135; LEX nr 2678604. Orzeczenie to zapadło jednomyślnie, a przepis ten utracił moc w powyższym zakresie $\mathrm{z}$ dniem 18 czerwca $2019 \mathrm{r}$.

${ }^{9}$ Wyrok TK z dnia 19 czerwca 2019 r., P2-/17, s.17. 
cą analizować, czy w realiach danej sprawy należy dokonać połączenia kary pozbawienia wolności z karą ograniczenia wolności i orzec karę łączną pozbawienia wolności, czy też odrębnie te kary wykonać"10. Trafnie zauważa Anna Dziergawka, że obecnie uzasadnienie łączenia kar różnorodzajowych w trybie i na zasadach określonych w art. $87 \S 1$ k.k. odnosi się wyłącznie do sytuacji, gdy brak jest możliwości wymierzenia na podstawie art. $87 \S 2$ k.k. dwóch kar łącznych - pozbawienia wolności oraz ograniczenia wolności, które ze swojej istoty będą wykonywane nie jednocześnie, lecz sekwencyjnie ${ }^{11}$.

Zastępcza kara pozbawienia wolności, jako ostateczna forma wykonania orzeczonej kary ograniczenia wolności, która jest niewykonalna pod przymusem, nie jest karą izolacyjną. Ze względu na ten aspekt, jak podnosi się w doktrynie, jej wykonanie nie może być zabezpieczone stosowaniem przymusu bezpośredniego w postaci zatrzymania skazanego i doprowadzenia go do odbycia kary ${ }^{12}$. Zastępcza kara pozbawienia wolności zmienia dolegliwości o charakterze wolnościowym zastosowane przez sąd w wyroku orzekającym karę ograniczenia wolności na dolegliwość izolacyjną w postaci faktycznego pozbawienia skazanego wolności $\mathrm{w}$ ramach zastępczej kary pozbawienia wolności. Nie ulega wątpliwości, że kara ograniczenia wolności orzeczona w postaci rozbudowanej, tj. z uwzględnieniem określonych obowiązków, o których mowa w art. $72 \S 1$ pkt 2-7a k.k., może być stosunkowo dotkliwa, zwłaszcza dla części skazanych, np. z uwagi na ich ogólną społeczną nieodpowiedzialność, przez którą szansa na wykonanie kary ograniczenia wolności jest mniejsza ${ }^{13}$. Wprawdzie, jak zauważa Zofia Sienkiewicz, dobór i liczba nakładanych obowiązków przy orzekaniu kary ograniczenia wolności należy do swobodnego uznania sędziowskiego, jednakże sędzia musi uwzględniać tu wskazania ogólnych dyrektyw sądowego wymiaru kary, a zatem kierować się celami zarówno sprawiedliwościowymi, jak i prewencyjnymi. Nadto, autorka ta wskazuje na możliwość modyfikacji tych obowiązków w postępowaniu wykonawczym zgodnie z art. $35 \S 4$ k.k., przy odpowiednim stosowaniu w tym zakresie art. 74 k.k. ${ }^{14}$ Tak czy inaczej, po uprawomocnieniu się wyroku dotychczasowy oskarżony, a obecnie skazany, za sprawą swojego zachowa-

\footnotetext{
${ }^{10}$ Postanowienie SN z dnia 14 stycznia 2021 r., V KO 116/20, Legalis nr 2524800.

${ }^{11}$ A. DzIERgawKa, Kontrowersje dotyczace taczenia kar pozbawienia wolności i ograniczenia wolności (art. 87 \& 1 i 2 k.k.), „Prokuratura i Prawo” 2019, nr 10, s. 46.

${ }^{12}$ Zob. M. CENDROWSKA, Sylwetka kuratorów sądowych, s. 80.

${ }^{13} \mathrm{~Np}$. K. Stasiak jedną z przyczyn takiego stanu dostrzega w uzależnieniu od alkoholu osób na nią skazanych. K. STASIAK, Kara ograniczenia wolności i jej rola $w$ resocjalizacji sprawców przestępstw, „Nauka, Gospodarka, Społeczeństwo” 2012, nr 1, s. 286.

${ }^{14}$ Z. SiENKIEWICZ, Z problematyki kary ograniczenia wolności w świetle nowelizacji kodeksu karnego, „Nowa Kodyfikacja Prawa Karnego” 2018, t. 48, s. 57-58.
} 
nia (faktów dokonanych) sprzecznego z postulatem z przepisu art. $53 \S 2$ k.k.w. może zgodnie ze swoją wolą sprawić, że np. „uwolni się” od tej konkretnej kary i związanych z nią obowiązków. Wprawdzie doprowadzi to w rezultacie do zarządzenia wykonania wobec niego zastępczej kary pozbawienia wolności (obligatoryjnego albo fakultatywnego - ale o tym będzie mowa dalej) w przypadku, gdy będzie on uchylał się od wykonania kary ograniczenia wolności, przy czym zastępcza kara pozbawienia wolności w jego subiektywnej ocenie na daną chwilę może w ogólnym rozrachunku jawić mu się jako mniej dotkliwa i bardziej przez niego akceptowalna, niż pierwotnie orzeczona wobec niego kara ${ }^{15}$. Skazany, który z premedytacją uchyla się od odbycia prawomocnie orzeczonej kary, nie powinien mieć możliwości dalszego jej odwlekania, byłoby to bowiem niczym innym jak nagradzaniem jego prawnie niepożądanego zachowania.

\section{ROZPOCZĘCIE WYKONANIA KARY OGRANICZENIA WOLNOŚCI}

Rozpoczęcie odbywania kary w formie nieodpłatnej, kontrolowanej pracy na cele społeczne następuje w dniu, w którym skazany przystąpił do wykonywania wskazanej pracy (art. 57a $\S 1$ k.k.w.), a w wypadku potrącenia następuje w pierwszym dniu okresu, w którym dokonuje się potrącenia skazanemu wynagrodzenia za pracę (art. 57a $\S 2$ k.k.w.). Instrument służący uelastycznieniu kary ograniczenia wolności na etapie wykonawczym - jak zauważa Magdalena Zglińska - stanowi art. 63b k.k.w., wprowadzający możliwość rozliczenia godzin pracy na cele społeczne w okresach innych niż miesięczne ${ }^{16}$. Obie przewidziane w art. 57a k.k.w. sytuacje mają w tej perspektywie - zdaniem Tomasza Kalisza - charakter wyjątkowy. Mimo przymiotu prawomocności - pisze ów autor - kara ograniczenia wolności do czasu zaistnienia wskazanych w tym przepisie okoliczności nie ma statusu wykonalności i nie może być realizowana ${ }^{17}$. Orzeczenie zastępczej kary pozbawienia wolności oraz wszystkie inne czynności zmierzające do osadzenia skazanego na nią powinny - co do zasady - następować bezzwłocznie, lecz nie później niż 14 dni od daty uprawomocnienia lub od daty zwrotu akt sądowi pierw-

${ }^{15}$ D. Mucha, Zgoda skazanego na orzeczenie kary, s. 85. Podobnie zob. K. STASIAK, Kara ograniczenia wolności, s. 286.

${ }^{16}$ M. ZGLIŃSKA, Ewolucja kary ograniczenia wolności, „Kortowski Przegląd Prawniczy” 2017, nr 1 s. 161.

${ }^{17}$ T. KALISZ, Wszczęcie i data zakończenia postępowania $w$ przedmiocie wykonania kary ograniczenia wolności, „Nowa Kodyfikacja Prawa Karnego” 2016, t. 40, s. 14-15. 
szej instancji. Postanowienia wydane w postępowaniu wykonawczym wykonalne $\mathrm{z}$ chwilą ich wydania kierowane są do wykonania $\mathrm{w}$ dniu ich wydania - datę skierowania orzeczenia do wykonania stanowi data podpisania zarządzenia o wykonaniu takiego orzeczenia $-\S 391$ ust. 1 i 2 r.u.s.p. ${ }^{18}$

Sąd nadzorujący wykonanie kary ograniczenia wolności, którym jest de facto na podstawie art. $55 \S 1$ i 2 k.k.w. sąd rejonowy, w którego okręgu kara ta jest lub ma być wykonywana na podstawie czynności sądowego kuratora zawodowego, który w trybie przepisu $\S 2$ art. 55 k.k.w. organizuje i kontroluje wykonywanie kary ograniczenia wolności oraz obowiązków nałożonych na skazanego, powinien na takie sytuacje reagować szybko i zdecydowanie, respektując $\mathrm{w}$ tym zakresie m.in. wolę ustawodawcy wyrażoną $\mathrm{w}$ przepisach normy prawnej art. 9 k.k.w. Tak ukształtowana kara ograniczenia wolności zdaniem Andrzeja Jezuska - przypomina pod wieloma względami okres próby łączony $\mathrm{z}$ nakazami i zakazami nałożonymi na sprawcę $\mathrm{w}$ razie zastosowania warunkowego zawieszenia wykonania kary pozbawienia wolności ${ }^{19}$. Należy przypomnieć, że jeżeli ustawa nie przewiduje za dane przestępstwo kary pozbawienia wolności, to górna granica zastępczej kary pozbawienia wolności na podstawie art. $65 \S 2$ k.k.w. nie może przekraczać sześciu miesięcy ${ }^{20}$. Z kolei w przypadku uchylania się skazanego od świadczenia pieniężnego lub obowiązków orzeczonych na podstawie art. $34 \S 3$ k.k., zarządzenie przez sąd wykonania zastępczej kary pozbawienia wolności ma charakter fakultatywny (art. $65 \S 1$ k.k.w.). „Podjęcie decyzji w tym przedmiocie - jak pisze jeden z komentatorów - zostało pozostawione dyskrecjonalnej ocenie sądu, który w zależności od konkretnego przypadku, zwłaszcza postawy skazanego w toku odbywania kary, będzie mógł rozważyć, czy pomimo niewykonania świadczenia pieniężnego lub obowiązku (lub obowiązków) konieczne jest zarządzenie izolacyjnej formy wykonania kary ograniczenia wolności" ${ }^{\prime 2}$.

Reasumując powyższe uwagi, należy stwierdzić, że skazany ma podane informacje m.in. o konsekwencjach wynikających z uchylania się od odbywania kary w związku z udzielonym mu pouczeniem przez sądowego kuratora

\footnotetext{
${ }^{18}$ Rozporządzenie Ministra Sprawiedliwości z 19 września 2019 r. - Regulamin urzędowania sądów powszechnych, Dz.U. z 2019 r., poz. 1141 ze zm. [dalej: r.u.s.p.].

${ }^{19}$ A. JEZUSEK, Sekwencja kary pozbawienia wolności i kary ograniczenia wolności jako reakcja na popetnienie przestępstwa (art. 37 b k.k.), „Państwo i Prawo” 2017, nr 5, s. 90.

${ }^{20}$ Przywrócenie tej regulacji było postulowane w doktrynie m.in. przez Radosława Giętkowskiego. Zob. R. GIĘTKOWSKI, Prawne zmiany w zakresie wykonywania kary ograniczenia wolności, „Przegląd Sądowy” 2012, nr 6, s. 58.

${ }^{21}$ K. DĄBKIEwICZ, Kodeks karny wykonawczy. Komentarz. Komentarz do art. 65 k.k.w., LEX, teza 2.
} 
zawodowego na podstawie art. 57 k.k.w. o przysługujących mu prawach i obowiązkach oraz konsekwencjach wynikających z uchylania się od odbywania kary $^{22}$. W przypadku kary ograniczenia wolności nie ma faktycznej możliwości zastosowania przymusu bezpośredniego wobec skazanego w celu wyegzekwowania tej właśnie kary w postaci zatrzymania i doprowadzenia do odbycia kary, gdyż kara ograniczenia wolności nie jest przecież karą izolacyjną ${ }^{23}$.

\section{ZACHOWANIE SKAZANEGO I OBOWIĄZKI KURATORA}

W razie ustalenia, że skazany uchyla się (a więc długotrwale i uporczywie) od odbywania kary ograniczenia wolności w zakresie jej głównych obowiązków z normy prawnej art. 34 k.k., określenie kary zastępczej jest obligatoryjne. Przed podjęciem przez sąd decyzji o zastępczej karze pozbawienia wolności sąd wyznacza posiedzenie, na które wzywa skazanego, a jeśli ten stawi się na nie, wtedy go wysłuchuje ${ }^{24}$. W przypadku gdy dopatrzy się, że skazany uchyla się od odbywania orzeczonej wobec niego kary ograniczenia wolności, sąd na podstawie art. 18a pkt 3 k.k.w. orzeka o zastępczej karze pozbawienia wolności. W sprawie, w której takie posiedzenie sądu zostało wyznaczone, np. z uwagi na złożenie przez kuratora sądowego w trybie przepisu art. $57 \S 2$ i 3 k.k.w. w zw. z art. $173 \S 2$ pkt 8 i 9 k.k.w. wniosku w przedmiocie orzeczenia kary zastępczej, w sytuacji gdy sąd nie dopatrzy się po stronie skazanego uchylania się od odbywania kary ograniczenia wolności, wówczas wydaje postanowienie, którym to nie uwzględnia takiego wniosku kuratora sądowego.

Na marginesie powyższych uwag warto dodać, że obecne brzmienie przepisu art. $57 \S 2$ k.k.w. narzuca kuratorowi zawodowemu działanie zautomatyzowane przy braku możliwości pozostawienia sądowemu kuratorowi zawodowemu marginesu oceny w trzech sytuacjach, tj. gdy skazany: a) nie stawi się na wezwanie kuratora w terminie; b) pouczony o prawach i obowiązkach oraz konsekwencjach związanych z wykonaniem nieodpłatnej kontrolowanej pracy na cele społeczne oświadczy, że nie wyraża zgody na podjęcie pracy

\footnotetext{
${ }^{22}$ Skazany podpisuje dwa egzemplarze pouczenia, brak na nich podpisu skazanego to negatywna przesłanka o charakterze formalnym do przypisania skazanemu złej woli. ( $\$ 25$ ust. 5 i 6 rozporządzenia Ministra Sprawiedliwości z dnia 13 czerwca 2016 r. w sprawie sposobu i trybu wykonywania czynności przez kuratorów sądowych w sprawach karnych wykonawczych, Dz.U. z 2016 r., poz. 969).

${ }^{23}$ D. Mucha, Zgoda skazanego na orzeczenie kary, s. 86.

${ }^{24}$ Zgodnie z przepisami przesyłka pocztowa dwukrotnie awizowana i nieodebrana jest składana do akt ze skutkiem doręczenia.
} 
w wyznaczonym terminie; c) w inny sposób uchyla się od odbywania kary ograniczenia wolności lub wykonania ciążących na nim obowiązków.

$\mathrm{W}$ przypadku zaistnienia jednej $\mathrm{z}$ ww. sytuacji kurator zawodowy ma ustawowy obowiązek skierowania do sądu wniosku o orzeczenie kary zastępczej, który przesyła z aktami sprawy i zakreśla sprawę w stosownym wykazie. Od tego momentu kurator nie prowadzi już postępowania. Ostatecznie o jej zastosowaniu decyduje oczywiście sąd rozpoznający taki wniosek kuratora, który nie jest związany takim wnioskiem kuratora. Zbiór możliwych rozstrzygnięć, jakie może wydać sąd, będzie różny i uzależniony od momentu, w którym sąd będzie orzekał, a to ze względu na fakt, że kara ograniczenia wolności ma terminowy charakter. Trafne spostrzeżenie w tym zakresie poczynili Michał Jankowski i Wojciech Sych, dla których fakt, że posiedzenie sądu odbywa się już po zakończeniu okresu wykonania kary ograniczenia wolności skutkuje tym, że „sąd nie tylko nie może na poczet kary zaliczyć pracy skazanego wykonywanej po tym okresie, o ile do takiej nieprawidłowości doszło, lecz także nie może w jakimkolwiek trybie odesłać sprawy kuratorowi i nakazać skazanemu wykonywanie pracy w dalszym ciągu"25.

Znamienne jest to, że ustawodawca w tym zakresie niewiele wymaga od kuratora zawodowego poza np. tylko stwierdzeniem, że skazany nie stawił się do niego w wyznaczonym terminie, i to bez obowiązku zbadania przyczyny niestawienia się skazanego, ograniczając ten obowiązek tylko do formalnego sprawdzenia, czy wezwanie zostało skazanemu prawidłowo doręczone przez operatora pocztowego. Bardziej dokładny jest już z kolei prawodawca w osobie ministra sprawiedliwości, który w przepisach rozdziału 3 zatytułowanego „Wykonywanie kary ograniczenia wolności i pracy społecznie użytecznej" w swoim rozporządzeniu z dnia 13 czerwca 2016 r. w sprawie sposobu i trybu wykonywania czynności przez kuratorów sądowych w sprawach karnych wykonawczych te obowiązki kuratorów zawodowych w pewnym zakresie doprecyzowat ${ }^{26}$.

Ustawodawca samo konkretne uprawnienie do uznania, czy niewłaściwe zachowanie skazanego było uporczywe, przekazał wyłącznie do sądu, nie zaś do sądowego kuratora zawodowego, który stwierdza tylko fakt, ale nie ma uprawnień do tego, by ocenić zachowanie skazanego jako uchylanie się od odbywania kary. Oczywiste wydaje się więc, że kuratorzy zawodowi nie powinni kierować wniosku o orzeczenie kary zastępczej, gdy nie ma żadnych wątpliwości, że niestawiennictwo skazanego wynikło z okoliczności od

\footnotetext{
${ }^{25}$ M. JANKOWSKI, W. SYCH, Wykonywanie kary ograniczenia wolności. Zagadnienia węzłowe $w$ świetle praktyki, Warszawa: Instytut Wymiaru Sprawiedliwości 2017, s. 45.

${ }^{26}$ Zob. przyp. 14.
} 
niego niezależnych. Założenia racjonalnego ustawodawcy pozwalają więc przyjąć w takim stanie rzeczy, że skoro ustawodawca „nie mówi” niczego bez potrzeby, to także należy respektować to, czego ustawodawca „nie powiedział wprost". Tym samym na sądowym kuratorze zawodowym jako organie postępowania wykonawczego, jak podnosi się w doktrynie, ciąży obowiązek dokonania wstępnej oceny faktów i wyciągnięcia $z$ nich odpowiednich wniosków dotyczących tego, czy zachowanie skazanego może być w ogóle rozpatrywane w kategoriach uchylania się od odbywania kary ograniczenia wolności ${ }^{27}$.

\section{ZASTĘPCZA KARA POZBAWIENIA WOLNOŚCI}

W posiedzeniu sądu w przedmiocie zarządzenia wykonania zastępczej kary pozbawienia wolności na podstawie przepisu art. $65 \S 3$ k.k.w. mają prawo wziąć udział: prokurator, sądowy kurator zawodowy, skazany oraz jego obrońca, przy czym niestawiennictwo osób, które zostały należycie zawiadomione o terminie i celu posiedzenia, jak stanowi przepis art. $22 \S 1$ a k.k.w., nie wstrzymuje rozpoznania sprawy $-\mathrm{z}$ wyłączeniem tzw. obrony obligatoryjnej. W pierwszej kolejności sąd doręcza skazanemu postanowienie z pouczeniem o zażaleniu. „Możliwość wniesienia środka zaskarżenia - pisze Gabriela Piekut - należy odczytywać jako uprawnienie do wniesienia zażalenia nie tylko na rozstrzygnięcie w przedmiocie zarządzenia wykonania kary zastępczej (czy to pozytywnym, czy negatywnym), lecz również na określenie przez sąd wymiaru kary zastępczej (pozostałej do odbycia)"28. Następnie po uprawomocnieniu się postanowienia sąd tak orzeczoną karę wprowadza do wykonania w trybie art. $65 \S 1$ k.k.w. oraz $\S 391$ ust. 1. 2. r.u.s.p. Wymierzenie kary zastępczej zależy więc od tego, czy w ocenie sądu konkretne zachowanie się skazanego zostanie uznane za uchylanie się od odbywania tej kary, czy też nie, przy czym w judykaturze i jurysprudencji pojęcie „uchylanie się" jest raczej wąsko interpretowane. Przykładowo - Sąd Najwyższy w swojej uchwale z dnia 20 czerwca 1979 r., VI KZP 6/79 przyjął, że uchylanie się

${ }^{27}$ G. PIEKUT, Konsekwencje uchylania się od odbywania kary ograniczenia wolności, ,Nowa Kodyfikacja Prawa Karnego” 2016, t. 39, s. 143; R. GIĘTKOWSKI, W sprawie nowych regulacji dotyczacych wykonywania kary ograniczenia wolności, „Przegląd Sądowy” 2010, nr 9, s. 7; A. ORNOWSKA, Kara ograniczenia wolności w świetle nowelizacji kodeksu karnego i kodeksu wykonawczego, Opole: Scriptorium 2013, s. 258-259; K. POSTULSKI, Kodeks karny wykonawczy. Komentarz do art. 57 k.k.w. - LEX, teza 22-23.

${ }^{28}$ G. PIEKUT, Konsekwencje uchylania się od odbywania kary, s. 144. 
„oznacza takie zachowanie się skazanego, które jest wyrazem jego negatywnego stosunku do tej kary czy nałożonych w związku z nią obowiązków, a więc wynika ze złej woli, nie zaś z innych przyczyn - obiektywnych lub nawet przez niego zawinionych" ${ }^{29}$. Uchylanie się skazanego od odbywania kary ograniczenia wolności należy uznać za sytuacje, kiedy to skazany ma świadomość ciążących na nim obowiązków nałożonych na niego określoną postacią kary oraz o negatywnych skutkach grożących mu w związku z ich niewykonaniem. W takiej to sytuacji sąd ocenia obiektywnie jego postępowanie pod kątem tego, czy miał on faktyczne możliwości, by wywiązać się z nałożonych na niego obowiązków w całości albo w części w danym okresie i miejscu do tego wskazanym przez właściwy organ wykonawczy. W doktrynie trafnie też podnosi się, że co do zasady jednorazowe niewykonanie przez skazanego ciążących na nim obowiązków jest niewystarczające do uznania, że zachodzi podstawa do zastosowania względem niego zastępczej kary pozbawienia wolności ${ }^{30}$.

Natomiast popełnienie przez skazanego w trakcie odbywania przez niego kary ograniczenia wolności przestępstwa stanowi wprawdzie rażące naruszenie prawa, ale nie należy go uznać za okoliczność istotną dla przebiegu kary ograniczenia wolności, jest to bowiem okoliczność prawnie obojętna dla zarządzenia wykonania w związku z jej zaistnieniem wobec takiego skazanego zastępczej kary pozbawienia wolności. Kara ograniczenia wolności jest przecież wyłącznie karą z katalogu kar z art. 32 k.k., a nie środkiem związanym $\mathrm{z}$ poddaniem sprawcy próbie. Pewne jest, że w aktualnym stanie prawnym kara ograniczenia wolności w związku z rażącym naruszeniem prawa przez skazanego nie może być zamieniona na zastępczą karę pozbawienia wolności - założenie przeciwne jest nieuprawnione. Jest ono bowiem niezgodne z obowiązującą regulacją.

Ustalenie przez sąd, iż skazany uchyla się od wykonania kary ograniczenia wolności, powoduje, że sąd zamienia ją na karę zastępczą. Przy czym to ustalenie sądu powinno zostać poczynione na podstawie ustalenia przez sąd faktów świadczących o tym, iż skazany nie wykonuje nałożonych na niego konkretnych obowiązków związanych z karą ograniczenia wolności oraz z nabraniem przez sąd przekonania będącego oceną tego, iż zachowanie skazanego cechuje w tym zakresie zła wola. Zarządzenie wykonania zastępczej kary pozbawienia wolności w miejsce kary ograniczenia wolności, od odby-

\footnotetext{
29 „Orzecznictwo Sądu Najwyższego - Izba Karna i Wojskowa” 1979, nr 9, poz. 89; LEX nr 19552.

${ }^{30}$ G. PIEKUT, Konsekwencje uchylania się od odbywania kary, s. 135.
} 
wania której skazany się uchyla, dopuszczalne jest - jak stwierdził Sąd Najwyższy - niezależnie od tego, czy upłynął już okres, na jaki karę ograniczenia wolności orzeczono, jeżeli skazany w tym czasie nie wykonał w całości nałożonego na niego obowiązku pracy ${ }^{31}$. „Jeżeli upłynął czas wykonania orzeczonej kary ograniczenia wolności - pisze Marcin Szewczyk - podjęcie decyzji o zarządzeniu kary zastępczej powinno każdorazowo poprzedzać orzeczenie wydane w trybie art. $64 \S 1$ k.k.w., w którym konieczne jest ustalenie, w jakiej części została ona przez skazanego wykonana. Następnie za niewykonaną karę ograniczenia wolności sąd powinien orzec karę zastępczą, na zasadach określonych w art. $65 \S 1$ k.k.w." ${ }^{32}$. Aby więc ustalić, że skazany odbył w całości karę ograniczenia wolności w formie przewidzianej w art. 34 § 1a pkt 1 k.k., konieczne jest łączne wystąpienie dwóch przesłanek w postaci: upływu okresu, na który karę orzeczono, oraz wykonania przez skazanego w całości obowiązku nieodpłatnej, kontrolowanej pracy na cele społeczne ${ }^{33}$. Orzeczenie sądu w tym przedmiocie jest decyzją względnie obligatoryjną ${ }^{34}$.

$\mathrm{W}$ momencie orzeczenia zastępczej kary pozbawienia wolności w miejsce kary ograniczenia wolności z mocy prawa wygasają praktycznie wszystkie ciążące na skazanym obowiązki - poza jednym, ale o tym będzie mowa poniżej. Jeżeli wyrok wymierzający karę ograniczenia wolności zawiera obowiązek naprawienia szkody, to traci on swój karnoprawny charakter. Cały czas jest jednak uważany za orzeczenie co do roszczeń majątkowych, któremu można nadać klauzulę wykonalności - art. 107 § 2 Kodeksu postępowania karnego ${ }^{35}$. Obowiązek ten nie wygasa, tylko jego niespełnienie przez skazanego nie jest zagrożone orzeczeniem kary zastępczej. „Orzeczenie kary zastępczej - jak trafnie zauważył Stanisław Zimoch, a następnie powtórzył przywołując go Radosław Giętkowski w swej publikacji - nie powoduje [...] utraty mocy samego wyroku skazującego, w którym taka kara została zastosowana" ${ }^{36}$. Po drugie, orzeczony środek kompensacyjny w dalszym ciągu

\footnotetext{
${ }^{31}$ M.J. SzewCZyK, Glosa do postanowienia Sądu Najwyższego z dnia 18 lipca 2019 r., sygn. V KK 353/18, „Prokuratura i Prawo” 2020, nr 10-11, s. 238 - w tej części glosa aprobująca.

${ }^{32}$ M.J. SzEWCZYK, Glosa, s. 239 - w tej części glosa krytykująca.

${ }^{33}$ Postanowienie SN z dnia 18 lipca 2019, V KK 353/18, Legalis nr 2230073; zob. uzasadnienie do postanowienia SN z dnia 26 listopada 2020 r., V KK 254/20, Legalis nr 2601892.

${ }^{34}$ K. POSTULSKI, Orzekanie i wykonywanie zastępczej kary pozbawienia wolności, „Probacja” 2013, [nr] 2, s. 64.

${ }^{35}$ Ustawa z 6 czerwca 1997 r. - Kodeks postępowania karnego, tekst jedn.: Dz.U. z 2021 r., poz. 534 [dalej: k.p.k.].

${ }^{36}$ R. GIĘTKOWSKI, Skutki uchylania się od odbywania kary ograniczenia wolności, „Państwo i Prawo" 2006, z. 7, s. 81-80.
} 
stosuje się względem skazanego, wobec którego orzeczono zastępczą karę pobawienia wolności.

W sytuacji wymierzenia zastępczej kary pozbawienia wolności przez sąd zastosowanie znajduje przelicznik z przepisu art. $65 \S 1$ zd. 2 k.k.w., zgodnie z którym jeden dzień kary zastępczej pozbawienia wolności jest równoważny dwóm dniom ograniczenia wolności, ,a także z uwzględnieniem faktu ewentualnego wykonania części kary ograniczenia wolności i zarządzeniem wykonania kary zastępczej w wymiarze kary ograniczenia wolności jedynie pozostałej do wykonania, przy zastosowaniu tego samego przelicznika" ${ }^{37}$. Przyjmując dopuszczalność analogii legis (oczywiście na korzyść skazanego) w procesie wykładni przepisów Kodeksu karnego wykonawczego ${ }^{38}$ w postaci art. $65 \S 1$, należy przyjąć, że sposób przeliczenia kary ograniczenia wolności na karę zastępczą pozbawienia wolności nie jest uzależniony od stopnia wykonania kary ograniczenia wolności, w tym zakresu pozostałych do wykonania obowiązków. „Należy przyjąć, że taki sam równoważnik obowiązuje przy zmianie na karę zastępczą całej, w ogóle niewykonanej kary ograniczenia wolności, choć - zgodnie z zasadami przyzwoitej legislacji - powinno to być w ustawie wprost" ${ }^{39}$. Przelicznik ten został wprowadzony w tej wysokości do polskiego systemu prawa już w Kodeksie karnym wykonawczym z 1969 r. ${ }^{40}$ Przy czym dzień, miesiąc, rok w wymiarze kary ograniczenia wolności na podstawie art. $127 \mathrm{~b}$ i $127 \mathrm{c}$ k.p.k. w zw. z art. 1 § 2 k.k.w. ma charakter terminu normatywnego i oznacza odpowiednio: okres 24 godzin liczony od chwili rzeczywistego pozbawienia wolności, miesiąc to $30 \mathrm{dni}$, a rok - 365 dni. Owe odesłanie do odpowiednich przepisów k.p.k. w zakresie ich odpowiedniego stosowania w postępowaniu wykonawczym ma fundamentalne znaczenie, ponieważ w przypadku kary ograniczenia wolności ustawodawca w przepisie art. $34 \S 1$ k.k. jako jednostki jej wymiaru nie podał dnia, który de facto stanowi jednostkę przeliczeniową.

Ponadto obowiązuje ograniczenie co do wymiaru zastępczej kary pozbawienia wolności, mianowicie, gdy ustawa karna nie przewiduje za dane

${ }^{37}$ R. PietruszKa, Nowa treść kary ograniczenia wolności, „Nowa Kodyfikacja Prawa Karnego" 2015 , t. 36 , s. 58 .

${ }^{38}$ Zob. uzasadnienie do uchwały SN z dnia 24 lutego 2010 r., I KZP 30/90, OSNKW 2010, nr 4, poz. 31; LEX nr 558099.

${ }^{39}$ R. GiętKowski, Prawne zmiany, s. 60.

${ }^{40} \mathrm{~W}$ doktrynie można spotkać się z głosami krytykującymi ten przelicznik jako zbyt wysoki, np. R. GIĘTKOWSKI, Skutki uchylania się od odbywania kary, s. 78-79; J. WOJCIECHOWSKA, Kara ograniczenia wolności w świetle projektów Kodeksu karnego i wykonawczego z $1991 \mathrm{r}$., [w:] Problemy kodyfikacji prawa karnego. Księga ku czci Profesora Mariana Cieślaka, red. S. Waltoś [i in.], Kraków: Uniwersytet Jagielloński 1993, s. 191. 
przestępstwo kary pozbawienia wolności, to górna granica zastępczej kary pozbawienia wolności, orzekanej bezpośrednio zamiennie za karę ograniczenia wolności, nie może przekroczyć sześciu miesięcy. A contrario należy wnioskować, że kara zastępcza pozbawienia wolności może też zostać wymierzona, gdy za pierwsze przestępstwo ustawa nie przewidywała możliwości orzeczenia kary izolacyjnej.

W okolicznościach, gdy skazany wykonał obowiązki wynikające z istoty kary ograniczenia wolności i pozostałe obowiązki z nią związane $\mathrm{z}$ wyjątkiem jednego z tych obowiązków, np. w związku z naprawieniem szkody, wówczas wymiar kary zastępczej należy ustalić kierując się wskaźnikami i zamiennikami określonymi w art. 65 k.k.w. od momentu, kiedy skazany przestał wykonywać jeden z obowiązków sankcji.

Należy mieć na uwadze, że przy okazji orzeczenia zastępczej kary pozbawienia wolności $w$ jej niewielkim wymiarze, a który to jej wymiar będzie rezultatem zastosowania ustawowego uniwersalnego przelicznika kary $\mathrm{z}$ art. $65 \S 1$ k.k., skazany odbędzie faktycznie karę zastępczą pozbawienia wolności, zanim wdrożone zostaną wobec niego wszystkie procedury wymagane do tego, by móc ostatecznie umieścić go w konkretnym zakładzie karnym. W przypadku zastępczej kary pozbawienia wolności ową karę wymierza się również w dniach, co stanowi wyjątek od zasady wymierzania kary pozbawienia wolności wyłącznie w miesiącach i latach ${ }^{41}$. Przy czym - jak zauważa trafnie Radosław Giętkowski - przepis art. $63 \S 1$ k.k. sugeruje korzystne dla skazanego przeliczenie dni kary ograniczenia wolności na zastępczą karę pobawienia wolności. Jeśliby liczba dni kary ograniczenia wolności podlegająca zamianie na karę pozbawienia była nieparzysta, by otrzymać pełną liczbę dni pozbawienia wolności, powinno się ją zastąpić przed zamianą najbliższą niższą liczbą parzystą ${ }^{42}$. Zastępcza kara pozbawienia wolności w swym założeniu co do zasady na podstawie przepisu art. $99 \S 2$ k.k.w. jest wykonywana w systemie zwykłym i w oddzieleniu od skazanych na bezwzględną karę pozbawienia wolności z art. 32 pkt 5 k.k.

W przypadku zarządzenia przez sąd wykonania wobec skazanego zastępczej kary pozbawienia wolności skazany może dla uniknięcia odbycia tej

${ }^{41}$ Zakaz wymierzania kary pozbawienia wolności w dniach (art. 37 k.k.) nie dotyczy również na zasadzie wyjątku dwóch sytuacji, tj. gdy sąd orzeka karę łączną pozbawienia wolności, jeżeli łączeniu podlegają kara pozbawienia wolności z karą ograniczenia wolności (art. 87 k.k.), oraz przy orzekaniu wykonania zastępczej kary pozbawienia wolności w związku z uchyleniem się od odbywania kary ograniczenia wolności (art. $65 \S 2$ i 3 k.k.w.).

${ }^{42}$ R. GIĘTKOWSKI, Kara ograniczenia wolności w polskim prawie karnym, Warszawa: Wolters Kluwer 2007, s. 172. 
formy kary przystąpić do jej odbywania lub też obok tego złożyć do akt sprawy pisemne oświadczenie, iż podejmie się odbywania kary ograniczenia wolności oraz że podda się rygorom z nią związanym, przy czym może to oświadczenie złożyć samo albo wraz z wnioskiem o wstrzymanie wykonania zastępczej kary pozbawienia wolności.

Na powyższe postanowienie przysługuje zażalenie, przy czym skazanemu przysługuje ono wówczas, gdy sąd nie uwzględnił jego wniosku o wstrzymanie wykonania zastępczej kary pozbawienia wolności z uwagi na złożenie przez niego pisemnego oświadczenia. Nie jest natomiast prawnie dopuszczalne ponowne wstrzymanie tej samej zastępczej kary pozbawienia wolności. Możliwe jest jednak wstrzymanie w każdym czasie wykonania zastępczej kary pozbawienia wolności, które następuje z mocy prawa do czasu wykonania orzeczonej kary ograniczenia wolności - art. 65a § 1, 5 i 6 k.k.w.

Orzeczenie zastępczej kary pozbawienia wolności w miejsce kary ograniczenia wolności co do zasady powinno nastąpić tylko w sytuacjach wyjątkowych, a instytucja wstrzymania jej wykonania w trybie art. 65a $\S 1$ k.k.w. tylko tę wyjątkowość potwierdza, podobnie jak wolę ustawodawcy co do tego, by kara pierwotna $\mathrm{z}$ wyroku skazującego została zachowana i odbyta przez skazanego. Rację ma więc Radosław Giętkowski, pisząc, że decyzja sądu co do zawieszenia wykonania kary ograniczenia wolności, mimo że ma charakter fakultatywny, to jednak ,co do zasady powinna być pozytywna, chyba że prawdopodobieństwo wykonania kary ograniczenia wolności jest nadzwyczaj nikłe" ${ }^{43}$.

\section{WNIOSKI}

Kończąc przedmiotowe rozważania w kontekście oceny obecnej regulacji de lege lata stwierdzić należy, że możność odbycia kary zastępczej pozbawienia wolności za przestępstwa i przestępstwa skarbowe w systemie dozoru elektronicznego w trybie art. 43lb k.k.w. stanowi bardzo dobre rozwiązanie ${ }^{44}$. Tytułem zaś wniosków de lege ferenda należałoby postulować zmianę treści przepisu art. $87 \S 1$ k.k., tak by obligatoryjnie zobowiązywał on sąd do orzekania w ramach kary łącznej kary z możliwością sekwencyjnego odby-

\footnotetext{
${ }^{43}$ R. GiĘTKOwSKI, Skutki uchylania się od odbywania kary, s. 75.

${ }^{44}$ Przepisy prawne dotyczące warunków i trybu orzekania o udzieleniu zezwolenia na odbycie kary pozbawienia wolności w systemie dozoru elektronicznego, obowiązków i praw skazanego zawarte są w rozdziale VIIa pt. „System dozoru elektronicznego” Kodeksu karnego wykonawczego.
} 
wania orzeczonych kar, tzn. w pierwszej kolejności orzeczonej kary pozbawienia wolności, ale już nieprzedłużonej przez przeliczenie na nią kary ograniczenia wolności, a następnie kary ograniczenia wolności, która powinna być przeliczana raczej w stosunku 3:1, a nie jak to jest obecnie: 2:1. Nadto, sąd powinien mieć możliwość osobnego łączenia kar ograniczenia wolności i kar pozbawienia wolności, które tak połączone wykonywane byłyby oddzielnie w ustalonej przepisem kolejności. Takie rozwiązanie mogłoby językowo nawiązywać do znanego sformułowania, jakim posłużył się ustawodawca w przepisie art. $37 \mathrm{~b}$ zd. 2 k.k., w którym to kategorycznie ustalono kolejność wykonywania sekwencyjnego kary pozbawienia wolności przed karą ograniczenia wolności określeniem „w pierwszej kolejności wykonuje się wówczas" $" 45$. W rezultacie ta ostatnia kara o charakterze wolnościowym stanowiłaby swoisty test próby dla skazanego po odbyciu przez niego kary pozbawienia wolności orzeczonej jako kara bezwzględna.

Wydaje się również, iż zmiany wymaga obecny stan prawny, który nie obliguje kuratora sądowego do poczynienia szerszych ustaleń w zakresie przyczyn, jakie mogły zaistnieć i legły u podstaw tego, że skazany nie stawił się przed nim w wyznaczonym terminie, co pozwala mu jego aktywność w tym zakresie ograniczyć do formalnego sprawdzenia, czy wezwanie zostało skazanemu prawidłowo doręczone. Taki stan prawny uznać należy za niewystarczający. Ponadto z uwagi na to, że pierwszeństwo ma wykładnia językowa przy dekodowaniu normy prawnej, która tę rzeczywistość prawną reguluje (opisuje), to nawet przy założeniu, że owe wyniki uzyskane przy zastosowaniu reguł językowych następnie mogą zostać zmodyfikowane przy zastosowaniu innych dyrektyw wykładni, np. celowościowej i logicznej (w szczególności reguły a minori ad maius, jak to jest w opisywanym przypadku), skłania do przyjęcia, iż taki stan zapisu jest niewystarczający i rodzący niepotrzebnie problemy interpretacyjne, bo tak uzyskana interpretacja (wniosek w drodze wnioskowania a fortiori) może rodzić istotne wątpliwości co do wykładni i stosowania przepisu. W moim przekonaniu wskazane propozycje przyczynić się mogą do tego, że omawiane zagadnienie z obszaru prawa karnego odnoszące się do orzekania zastępczej kary pozbawienia wolności w związku z uchylaniem się przez skazanego od odbywania kary ograniczenia wolności, z punktu widzenia szeroko rozumianego wymiaru sprawiedliwości przyczyni się do dobrego jego funkcjonowania.

${ }^{45}$ Szerzej o znaczeniu omawianego sformułowania pisał M. Małecki. Zob. M. MAŁECKI, Co zmienia nowelizacja art. 37 b.k.?, „Czasopismo Prawa Karnego i Nauk Penalnych”2016, nr 2, s. 19-52. 


\section{PIŚMIENNICTWO}

\section{Źródła prawa}

Konstytucja Rzeczypospolitej Polskiej z dnia 2 kwietnia 1997 r., Dz.U. z 1997 r., Nr 78, poz. 482 ze zm.

Ustawa z dnia 6 czerwca 1997 r. - Kodek karny, tekst jedn.: Dz.U. z 2020 r., poz. 1444.

Ustawa z dnia 6 czerwca 1997 r. - Kodeks postępowania karnego, tekst jedn.: Dz.U. z 2021 r., poz. 534.

Ustawa z dnia 6 czerwca 1997 r. - Kodeks karny wykonawczy, tekst jedn.: Dz.U. z 2021 r., poz. 53.

Ustawa z dnia 16 września 2011 r. o zmianie ustawy - Kodeks karny wykonawczy oraz niektórych ustaw, tekst jedn.: Dz.U z 2021 r., poz. 53.

Rozporządzenie Ministra Sprawiedliwości z dnia 19 września 2019 r. - Regulamin urzędowania sądów powszechnych, Dz.U. z 2019 r., poz. 1141 ze zm.

Rozporządzenie Ministra Sprawiedliwości z dnia 13 czerwca 2016 r. w sprawie sposobu i trybu wykonywania czynności przez kuratorów sądowych w sprawach karnych wykonawczych, Dz.U. z 2016 r., poz. 969.

\section{Literatura}

CENDROWSKA Monika: Sylwetka kuratorów sądowych oraz ich opinie na temat wykonywania kary ograniczenia wolności, [w:] Z problematyki badań empirycznych $w$ prawie karnym wykonawczym, red. A. Kwieciński, Wrocław: Wydawnictwo Uniwersytetu Wrocławskiego 2015, s. 67-85.

DĄBKIEwICz Krzysztof: Kodeks karny wykonawczy. Komentarz, LEX, teza 2.

DZIERgawKa Anna: Kontrowersje dotyczace taczenia kar pozbawienia wolności i ograniczenia wolności (art. 87 \& 1 i 2 k.k.), „Prokuratura i Prawo” 2019, nr 10, s. 42-65.

GIĘTKOWSKI Radosław: Skutki uchylania się od odbywania kary ograniczenia wolności, „Państwo i Prawo" 2006, nr 7, s. 78-91.

GIĘTKOWSKI Radosław: Kara ograniczenia wolności w polskim prawie karnym, Warszawa: Wolters Kluwer 2007.

GIĘTKOWSKI Radosław: W sprawie nowych regulacji dotyczacych wykonywania kary ograniczenia wolności, „Przegląd Sądowy” 2010, nr 9, s. 36-41.

GiĘTKOwSKI Radosław: Prawne zmiany w zakresie wykonywania kary ograniczenia wolności, „Przegląd Sądowy” 2012, nr 6, s. 54-62.

JANKOWSKI Michał, SYCH Wojciech: Wykonywanie kary ograniczenia wolności. Zagadnienia węzłowe w świetle praktyki, Warszawa: Instytut Wymiaru Sprawiedliwości 2017.

JEZUSEK Andrzej: Sekwencja kary pozbawienia wolności i kary ograniczenia wolności jako reakcja na popetnienie przestęstwa (art. 37 b k.k.), „Państwo i Prawo” 2017, nr 5, s. 80-94.

KALISZ Tomasz: Wszczęcie $i$ data zakończenia postępowania w przedmiocie wykonania kary ograniczenia wolności, „Nowa Kodyfikacja Prawa Karnego” 2016, t. 40, s. 11-23.

MAŁECKI Mikołaj: Co zmienia nowelizacja art. $37 b$ k.k.?, „Czasopismo Prawa Karnego i Nauk Penalnych" 2016, nr 2, s. 19-52. 
Mucha Dariusz: Zgoda skazanego na orzeczenie kary ograniczenia wolności - fikcja czy prawda?, „Opolskie Studia Administracyjno-Prawne” 2016, nr 1, s. 77-89.

Mucha Dariusz: Kara ograniczenia wolności - instrukcja obstugi, [w:] Kary jako podstawowe sankcje w prawie karnym, red. S. Hoc, D. Mucha, Opole: Scriptorium 2018, s. 167-182.

ORNOwSKA Alicja: Kara ograniczenia wolności w świetle nowelizacji kodeksu karnego i kodeksu wykonawczego, Opole: Scriptorium 2013.

PIEKUT Gabriela: Konsekwencje uchylania się od odbywania kary ograniczenia wolności, „Nowa Kodyfikacja Prawa Karnego" 2016, t. 39, s. 133-152.

PIETRUSZKa Renata: Nowa treść kary ograniczenia wolności, „Nowa Kodyfikacja Prawa Karnego" 2015, t. 36, s. 37-63.

POSTULSKI Kazimierz: Orzekanie $i$ wykonywanie zasteppzej kary pozbawienia wolności, „Probacja" 2013, [nr] 2, s. 47-71.

POSTULSKI Kazimierz: Kodeks karny wykonawczy. Komentarz, LEX, teza 22-23.

STASIAK Krzysztof: Kara ograniczenia wolności i jej rola w resocjalizacji sprawców przestęstw, „Nauka, Gospodarka, Społeczeństwo” 2012, nr 1, s. 257-288.

SiENKIEWICZ Zofia: Z problematyki kary ograniczenia wolności w świetle nowelizacji kodeksu karnego, „Nowa Kodyfikacja Prawa Karnego” 2018, t. 48, s. 47-65.

SzeWCZYK Marcin J.: Glosa do postanowienia Sadu Najwyższego z dnia 18 lipca 2019 r., sygn. V KK 353/18, „Prokuratura i Prawo” 2020, nr 10-11, s. 227-239.

WoJCIECHOwsKa Janina: Kara ograniczenia wolności w świetle projektów Kodeksu karnego i wykonawczego z 1991 r., [w:] Problemy kodyfikacji prawa karnego. Księga ku czci Profesora Mariana Cieślaka, red. S. Waltoś [i in.], Kraków: Uniwersytet Jagielloński 1993, s. 183-192.

ZgLiŃSKa Magdalena: Ewolucja kary ograniczenia wolności, „Kortowski Przegląd Prawniczy” 2017, nr 1, s. 156-162.

\section{NIEWYKONANIE KARY OGRANICZENIA WOLNOŚCI A ZASTĘPCZA KARA POZBAWIENIA WOLNOŚCI}

\section{Streszczenie}

Artykuł odnosi się do ostatniego etapu wykonawczego kary ograniczenia wolności w przypadku jej niewykonania przez skazanego na nią sprawcę przestępstwa w kontekście orzeczenia wobec niego zastępczej kary pozbawienia wolności. Autor dokonuje analizy i oceny zakończenia postępowania w zakresie kary ograniczenia wolności na skutek orzeczenia i wykonania kary zastępczej z uwagi na niepozytywne zakończenie wykonania kary ograniczenia wolności przez skazanych. W szczególności omawia jako najdalej idące alternatywne prawnie dopuszczalne rozwiązanie modyfikujące rodzaj orzeczonej pierwotnie kary i jej wymiar wymierzonej w orzeczeniu końcowym, wobec określonego sprawcy czynu zabronionego. Autor dokonuje analizy i oceny aktualnego stanu prawnego, podkreślając związane z nim niedopatrzenia i wątpliwości w ujęciu praktycznym, odnosząc je do uprawnień sądu i stron postępowania wykonawczego.

Słowa kluczowe: uchylanie się; zastępcza kara; wstrzymanie się 